\title{
On spatial modelling
}

\author{
Leonid Tchertov \\ Department of Culture, \\ The St. Petersburg Art School, \\ St. Petersburg, Fontanka 18, Russia \\ e-mail: Leonid.tchertov@gmail.com
}

\begin{abstract}
Spatial modelling concerns both the case when spatial structures have a modelling function and the case when such structures become modelled objects. In the article, spatial models are considered as the means of human activity in both external and internal aspects. External spatial models are tangible objects which have structural similarity with something different from them and can represent it for a subject. These external models can be interpreted on various mental levels: sensorial, perceptual, apperceptual and conceptual ones. Each of them is connected with a peculiar way of internal modelling. Both external and internal spatial models can have a productive or a reproductive character, which depends on whether they serve as patterns for reproduction or if they are copies of originals. It is possible to consider external models as spatial texts if they can be divided into a plane of expression and a plane of content which are connected with each other by a semiotic system. In particular, such division can be revealed in depictions in which the two planes of both depicting and depicted spaces are open for the eye and their connection is regulated by indexes of a special perceptographic code. So, depictions can be treated as spatial texts interpreted firstly on the perceptual level of internal modelling and, secondly, on the higher mental levels by means of other visual-spatial codes.

The article is divided into three parts. The first part contains a description of the basic concepts introduced in the author's interpretation. In the second part, these concepts are applied to description of spatial modelling and its semiotic means. In the third part an important special case of spatial modelling - combination of mimetic and semiotic means in formation of depictions - is discussed.
\end{abstract}

Keywords: modelling, spatial models, autonomic spaces, depictions, perceptographic code 


\section{Modelling in human activity}

\subsection{On the concept of the model}

In case of all distinctions in treatments of the concept of the model it usually has two main features. The first one touches upon the structural similarity between the modelled and the modelling in definite relations. The second feature concerns their functional connection, with one of them being able to replicate and represent another one. Structural similarity is a symmetrical relation because both the modelled and the modelling are equally similar to each other. Functional connection is, on the contrary, an asymmetrical relation, since both of its participants have different functions. Structural similarity without functional connection as well as functional connection without structural similarity is insufficient for modelling.

Still, such a general approach does not define what is called a "model": a modelled thing, a modelling work, or both of them. Although both the reproduced and the reproducing objects have a mutual functional connection to each other, different parts of their asymmetrical connection can be defined as a "model". The model can be understood, on the one hand, as a pattern for reproduction - such as, for example, a car design or a photo model. On the other hand, the concept of the model can be applied to something that reproduces such a pattern - in the same way a toy car resembles its prototype, or a photo is similar to a photo model. In the former case, the concept of the model is related to the reproduced prototype, whereas in the latter case this concept is related to something reproducing and replicating an original.

Both of these concepts can be considered as particular cases of the general concept of model. At this rate the model can be generally defined as something similarly and functionally connected with something else that is produced by a pattern or is itself a pattern for reproduction. Within the frame of this general definition one can speak about productive and reproductive models as two particular subclasses of the general class of models. These subclasses intersect, for instance, in cases when a copy of a productive model is a reproductive model of its pattern, though usually only one of these types is meant in the same context.

Both types of models can be similar to a correlative object to a greater or lesser degree, which depends on how many relations are involved in the comparison. The similarity between the modelling and modelled structures does not mean that both of them always have identical relations. For example, the relations "above-below" differ from the relations "warmer-colder", yet they can be in modelling relations, for instance in a thermometer, because both its spatial and degree scales have a similar order. In the present paper the relations common for modelled and modelling structures are called the basis of modelling. 
It is possible to speak about structural similarity in terms of likeness, resemblance or iconicity which are considered synonyms in this paper. According to the definition, each model has a similarity with the modelled object and hence they are in relations of iconicity. Thus the phrase 'iconic model' would be tautological.

Obviously, the concept of the model explained here is close to the notion of the 'iconic sign' suggested by Peirce as something representing an object "mainly by its similarity" (CP 2. 276, 2. 299; cf. Lotman 1967: 131). However, these two concepts are not identical because not all models have a representative function. Unlike reproductive models, the productive ones can occur without representing anything. For example, a portrait of a woman represents her; however, the same woman does not represent this portrait, although she can be called "a model" terminologically. Besides, in the present paper the concept of the sign is treated in a narrower sense than it is in Peircean semiotics (which will be discussed below, in Section 1.3.1). Therefore the term 'iconic sign' is not used in this paper.

\subsection{Modelling as an activity}

Modelling understood as creating and using models is an important property of human activity (cf. Lotman 1967: 130). Modelling mediates relations between subjects and objects as well as inter-subjective connections. Models are constructed as means of activity intended to achieve definite purposes of an acting subject; they are used in the processes of cognition or transformation of objects as well as for communication between subjects.

Like any other activity, modelling has its internal and external aspects. Understanding models as means of human activity helps to see the connection between them. The theory of human activity is based on the distinction between a subject and an object and considers both external and internal sides of the activity as well as their interaction. It thereby provides a possibility to speak about "interiorization" of the external activity in the development of thinking and about "internalization" of the ideas expressed by other subjects; this theory also makes it possible to speak about "exteriorization" of ideal projects (their embodiment in a material) or about the "externalization" of some ideas of a subject in a text. (cf. Vygotskij 1983: 142-145).

Therefore within the frame of activity theory one can distinguish internal models created in the mind of a subject, and external models which are constructed as material objects open to the subject's feelings. Both types of modelling correlate with each other. Internal mental models can be linked to external models, which also acquire sense only in connection with the mental processes of cognition, planning or evaluation. 
Both external and internal models can be created for different aims in various aspects of human activity. Modelling of the researched object is the essence of the cognitive processes. Internal cognitive models are formed on diverse mental levels and their structural similarity to objects of knowledge develops differently in the scientific theories of the conceptual level and in the images of the perceptual level. One can also speak about external models used as tools of knowledge and structural likening of ideal images to modelled objects. For instance, a globe is an external model with a cognitive function as far as it is intended for forming an internal model of Earth.

At the same time there are internal and external models which have, on the contrary, a productive character since they are created as original forms ("patterns" or "matrixes") intended for reproduction. They can be also formed for cognitive processes of thinking, e.g. schemes of reasoning in mathematics, logic or rhetoric. Such models can be created also in the projective processes as the means participating in transformation of some objects by a subject. In this case an ideal model is formed before the creation of the modelled objects and has a causal relation to it. This mental model can be externalized, for example, as a draft or a paper model of a future building. This way the mental projective model is embodied in the external model, which in its turn is a condition for further embodiment of the idea in the planned object.

Externalization of cognitive and projective internal models makes it possible for them to be internalized by other people and thereby is connected with the communicative aspect of activity. Every representation of a cognized or a transformed object is connected in human activity with the possibility of inter-subjective communication in relation to this object - as well as conversely every communication is connected with the possibility of containing a message about the represented objects. Due to the mutual communication of mental models between the individual and collective forms of the mind, both of them can develop in culture as two interactive aspects of the same semiosphere (cf. Vygotskij 1983; Lotman 1984).

Modelling as a human activity combines representative and communicative functions. Although mental models can be formed only in intra-subjective processes inseparable from the subject's mind, they can be expressed in the tangible form of external models, which stimulate formation of internal models by other people and mediate the processes of inter-subjective communication.

\subsection{Modelling and semiotic means}

\subsubsection{Models and signs}

External models as means of human activity can be compared with signs. Both of them mediate subject-object and inter-subjective relations as means of information 
connection combining an ability to represent objects for a subject, and to serve communication between different subjects (cf. the organon model of the sign, suggested by Karl Bühler: see Bühler 1934: 25). However, the representative function is performed by these means in a different way. The main ground of the representative functions for models is formed by their structural similarity with objects, whereas this ground by signs is based on some cultural conventions.

Signs are treated in this paper (as in the author's other works) as such means of human activity which serve for representation of objects and communication between subjects on the fully conventional grounds developed in culture and accepted in the minds of individuals (see Tchertov 1993, 1999, 2014). There are three constant components among variable elements of the sign connection between subjects. They are (1) the scheme of formation and recognition of a sign mediator; (2) the scheme of interpretation of this sign mediator; (3) the connection between these two schemes. These three components correlate respectively with the concepts 'form of expression', 'form of content' and 'sign function' of Louis Hjelmslev, who believed that the relation of these 'forms' to 'materials' of expression and of content is arbitrary (see Hjelmslev 1953, \$13). Semiotic means with the above-mentioned properties also correspond to the concept of the symbol according to Peirce, who wrote that "a Symbol is a sign which refers to the Object that it denotes by virtue of a law, usually an association of general ideas" (Peirce 1960: 143[249]). However, Peirce also noted the polysemy of the word 'symbol' (Peirce 1960: 167-168[297]). In another terminological tradition this word is treated as the semiotic means preserving a connection between an ambiguous sense and the way of its expression, which was a reason for Saussure to prefer the term 'sign' in order to denote arbitrary semiotic means (see Saussure 1977: 101).

The mechanism of functioning in the human activity, the cultural genesis of signs as well as their ability to represent any objects beyond the present situation are the features differentiating the sign-based way of information connection from natural signals and indexes which appear without intention of any subject and relate only to the present situation. This difference gives ground for linking the concept of the sign (in the narrow sense) only to the higher level of information connection unlike signals and indexes which are formed in natural biological systems or used in various technical devices.

At the same time, using the narrow concept of the sign does not exclude the possibility of applying semiotics to some natural and technical processes. It is possible to consider "semiotics of signals and indexes" together with "semiotics of sign means" in the sense described above, because all these means mediate an indirect information connection between the sender and the receiver of the message based on the semiotic system. According to this terminology, the concept of the semiotic system 
is not identical to the concept of the sign system and includes the later as a special case; it also includes the signal and indexical codes of the non-sign level (for more detail, see Tchertov 2014: 18-25).

Each thing that can be formed, recognized and interpreted according to the three components of the sign system mentioned above can be accepted as a sign satisfying the norms of this system. However, the participation of a thing in a process of communication in the sign function does not hinder the same thing from participating there in some other functions, particularly in the function of the model. Yet this different function is performed by such a thing in another way. So the difference between signs and models does not always coincide with the difference between things serving as mediators of communication; it is a difference not between the things, but between the ways or the principles of reference to a represented object.

\subsubsection{On the modelling functions of semiotic systems and texts}

Similarly, the systems of conventionally established signs can at the same time perform the modelling function in relation to the world which can be represented by them. Using the example of the colour spectrum which diverse languages have divided in different ways (Hjelmslev 1953, \$13), one can see that the arbitrary and differently established systems of such a division can be at the same time different models of the spectrum as a whole.

The systems of signs can be called the modelling systems insofar as they can create the internal models in intra-subjective processes of cognition and mental transformation of objects. Not only do these systems provide the means for external expression of a ready mental content, but they also give the means for the internal formation of this content. Any sign system always has the modelling function, as it contains a complex of sign types connected with the structured set of their meanings (see Lotman 1998: 26). This function is inherent even in a simple system of national flags and all the more in systems modelling broader spheres (cf. the idea regarding the borders of the language as the borders of the world for a subject in Wittgenstein 1922: 5.6.).

Semiotic systems of the signal-indexical level can also have a modelling function. So there is a complex of natural synesthetic codes regulating connections between modalities of feelings. In particular, the synesthetic code of colour links visible colours with definite heat sensations of warmth or cold. This semiotic system of natural indexes can be included in human activity and perform the modelling function, for example, it is intentionally used in art.

The modelling function can also be carried out by texts considered more complex formations than a single sign. The concept of text originated in the terminological tradition of linguistics and then was applied to the non-linguistic means of 
representation (e.g. Ivanov et al. 1998: 38; 3.1.0). In a broad semiotic sense, texts are complex constructions of meaningful units, which are formed and interpreted by definite semiotic systems. Texts in such a broad sense can be regulated not only by a verbal language, but also by non-linguistic, and even by non-sign, semiotic systems of signals and indexes.

Nevertheless, some important concepts developed in structural linguistics can be extended beyond its limits since they are relevant to many non-linguistic means. It is true for the opposition between the system and the text, derived from the distinction of langue and parole suggested by Saussure (cf. Saussure 1977; Hjelmslev 1953). Each system of signs or other semiotic units has to be common for some participants in communication so that they could exchange messages. The semiotic system can be a modelling system even if it remains in abscentia and is used unconsciously, while texts are open to feelings and exist in praesentia (cf. Saussure 1977: 156).

There is a ground for extending the opposition between "the plane of expression" and "the plane of content" to non-verbal means of representation and communication, insofar as they demonstrate differences between the representing forms and the represented content.

Every text can have a modelling function insofar as there is a similarity between the structures of the plane of expression and the structures of the plane of content. For instance, a verbal text like "veni, vidi, vici" does not only denote, but also models a temporal succession due to the similarity of the word order on the plane of expression to the order of acts represented on the plane of content. Similarly, a clock face can be considered a non-verbal text, which can also serve as a model of some temporal succession due to the similarity between the order of the visible numbers on the plane of expression and of invisible time units on the plane of content.

A text can be a model as far as it has some structural similarity to another object. So both concepts - 'model' and 'text' - can be applied to a meaningful object, though for different reasons. The means of representation treated as a model are directly related to the represented object and are similar to it, while treated as a text they first of all relate to the semiotic system mediating their relation to this object.

\subsubsection{Semiosis and mimesis in modelling}

In the present paper each code is treated as a system which regulates the translation and reception of information by signals, indexes or (conventional) signs and establishes the rules of their coding and decoding. A code is a system of "pre-information" which a recipient needs in order to receive and interpret any information via signals, indexes or signs (see Meyer-Eppler 1959: 251; Schreider 1974: 33). So not only these external bearers of information, but also the codes are mediators in the processes of indirect information connection. 
Unlike mediation by means of coding, there is an immediate information impact. Such direct impact occurs as a result of the "transposition" of structure in the causal chain (see Russell 1997: 271). Such "transposition of structure" can be also considered as a case of information connection understood in a broad sense - as determination of relations in the receiving system by relations of some other systems (for more detail, see Tchertov 1993, Ch. 1). For example, a trace of the hoof in nature or a cast sculpture in culture are determined by some patterns directly and receive the information without any coding system.

These printed or cast forms can serve as reproductive models of their patterns and can represent them for a subject. However, they have other basis for representation than signs. While the ground for the reference of the conventional sign to its denotatum is a semiotic system establishing the meaning of the sign, the reference of the model to an object is based on the structural similarity between them in several relations. Such similarity can occur in direct information impact such as printing, while information connection via semiotic means, or semiosis, is always an indirect process of coding and decoding.

By Charles Morris, "in semiosis something takes account of something else mediately, i.e. by means of a third something" (Morris 1971a: 19). According to Morris, semiosis is "a mediated-taking-account-of" and includes as a necessary component "interpretant" connected with "the disposition in an interpreter to respond" (Morris 1971b: 363). Such a disposition supposes pre-information, in other words, a code. So the process of semiosis is mediated not only by some external bearers of information but also by some inherent codes of interpreters. Semiosis cannot take place without a semiotic system regulating recognition and interpretation of external vehicles. Due to such a system, these external means of semiosis can be very different from the represented objects: indexes can be only implicated in a situation they point out, signs can have nothing in common with their denotata.

Apart from semiosis there is another principle of representation based on the imitation of represented object by something that looks like it. Using another ancient term this principle may be called mimesis. Although mimesis can serve as a way of hiding something via mimicry or camouflage, it can also be intentionally used as a way of representing an object or a person as something different. If the connection between the represented object and the semiotic means in semiosis is determined by a system of codes, the connection between the original and the copy in mimesis is set first of all by their mutual relations, when one of them imitates some properties of the other.

Both principles of representation - mimesis and semiosis - are involved in modelling, but in different ways. The mimetic principle is always there in modelling because structural similarity with another object is an inherent feature of each model. 
The semiotic principle does not always occur in modelling - at least because a model does not always serve to represent something else to somebody, and some productive models can be mechanically reproduced in their copies. However, the models can fulfill representative functions by using mimetic similarity together with the semiotic mechanisms of coding and decoding.

The relations between the mimetic and the semiotic principles of representation can vary in diverse types of modelling. The semiotic way of representation can be reduced to a minimum or even eliminated by reproducing an original by a copy. On the contrary, it can be the main principle of representation, as in case of languages and other semiotic systems.

\section{Spatial modelling}

\subsection{Spaces and spatial modelling}

\subsubsection{On spatial modelling}

It is possible to speak about spatial modelling based on the similarity between structures if at least one of them is formed by spatial relations. Hence spatial modelling concerns both the case when spatial structures have a modelling function and the case when such structures are the modelled objects. Accordingly, one can speak about spatial models in the former case and about models of space in the latter one. These cases can coincide but not always. Some spatial models can represent nonspatial objects and, vice versa, spatial structures can be represented by non-spatial models. For example, musical notation can have structural similarity with the melody it represents and thereby form a spatial model of its non-spatial structure. Conversely, the spatial structures built, for instance, by relations "above - below" can be modelled by the non-spatial order of "rising" or "falling" musical tones.

As modelling is a human activity, there is one more difference between its external and internal aspects. The spatial models of cognized or projected objects can have both external and internal forms, while the internal mental models of space can be correlated with external tools.

\subsubsection{Spatial relations and autonomic spaces}

Spatial structures are formed when some spatial relations build configurations of coexisting objects. These configurations can be transformed or destroyed by changes of the appropriate spatial relations. The class of spatial relations includes only the ones which can form or change arrangement of co-existing objects and their configurations. Particularly, contiguity and separation, inclusion and exclusion, isolation and intersection, etc. are spatial relations between objects and characterize the qualitative 
peculiarity of their arrangement in configurations. At the same time closer and farther, longer and shorter, more widely and more narrowly etc. are quantitative relations connected with the size of these objects and the distance between them.

Spatiality is always a property of formations consisting of such spatial relations. These formations include the above-mentioned spatial configurations as well as whole spaces. Unlike local configurations, the whole space is a formation where changes of partial spatial relations do not change its basic properties. Qualities like dimensionality, continuality or discreetness, openness or closeness and so on can be such invariants saved by the changes in some spatial relations. Since these constant properties can be different for various formations of that kind, it is possible to speak about diverse spaces in the plural. Each of them is an autonomous space if it has its own invariant properties and rules of formation. For example, a canvas covered by paints and a landscape painted on this canvas belong to different autonomous spaces, at least because the paints lie on a closed plane, whereas the landscape can be seen in a three-dimensional and open space. These autonomous spaces are formed by different spatial objects, ordered by different principles, have different measures of sizes, etc.

The concept of autonomous space can be related to complexes of real physical bodies as well as of ideal mathematical constructions and to the "conceptual spaces" as well as the "perceptual" ones, etc. (cf. Carnap 1922; Russell 1997). There are many autonomous spaces which are formed in culture according to some ideal norms and which at the same time have a physical embodiment. For example, the space of chess can be considered an autonomous formation of spatial relations regulated by its own rules different from the laws of physical space and the rules of other games.

Some autonomous spaces can be formed by semiotization, i.e., by establishment of definite semiotic systems regulating the organization and interpretation of spatial elements and structures carrying a meaning. The spaces semiotized in different ways by various systems have different properties.

The diverse autonomous spaces as well as several configurations formed in these spaces can be similar in some relations. So, diverse mathematical spaces can be the ideal models of the real physical space, a perceptual image can be an internal spatial model of an external spatial situation, etc.

\subsection{Spatial models}

\subsubsection{On the spatial and non-spatial models}

The class of spatial models includes elements that have a specific property: their modelling structures are formed by spatial relations and their modelling functions are performed due to the similarity of these spatial structures to something in a 
modelled object. Not all models share this property, even if they have spatial bearers. For instance, a telephone is a spatial object able to reproduce the sounds, which have a structural similarity to a phonic original. However, these reproduced sounds serve as a temporal acoustic, but not spatial, model. The spatial relations in this case serve only the condition of the modelling, but they do not form its basis.

Another peculiarity of spatial models is connected with the ability of spatial formations to contain at the same time a broad complex of relations observed as a whole. Two- and three-dimensional structures of spatial models can be perceived in the process of simultaneous synthesis of presented data as an integrated visual image (see Jakobson 1972).

\subsubsection{On the spatial models of space}

Spatial models of space occur if both the modelled and the modelling structures are formed by spatial relations or if diverse autonomous spaces are connected by the relation of modelling. For example, pictures, sculptures, architectural projects, ground maps, globes, etc. are external spatial models and models of space at the same time because spatial formations exist in both components of modelling.

If the objects from one space are modelled by the structures from another one, their various properties can be either reproduced or not: an ordinal organization, metric relations, connection between some changed configurations, etc. For example, diverse features of the same spatial situation can be modelled both by a topographic plan as well as by a drawing made according to the rules of linear perspective. While the rules of cartography require using the same scale for all represented objects, the rules of linear perspective, on the contrary, require systematic changing of scale for depicted objects depending of their remoteness.

\subsubsection{On the spatial models of non-spatial objects}

The spatial structures can be the models of non-spatial objects, because the similarity between the modelling and the modelled structures can be limited only by their order, even if the relations of these structures are not identical. For example, a genealogical tree can be a spatial model of non-spatial relations of kinship if the connection of the elements in both structures is organized in a unified way. The calendar can be considered a spatial model of time because the order of spatial relations between its signs corresponds to the order of relations between the denoted temporal units - days, months, etc. At the same time the presented spatial relations left-right and above-below are not identical to the represented temporal relations before-later.

Several models can be both spatial and temporal at the same time. The clock, for instance, is a spatial-temporal model of time because it models the structure of temporal processes by changing the position of the hands on the clock face. 


\subsection{The models of space}

\subsubsection{On the verbal and derived models of space}

Spatial models are always built by the spatial relations while models of space can be also formed by non-spatial relations, for example, between the meanings of words. Unlike the above-mentioned external models of space, verbal language is a modelling system, which has the means for internal modelling of many various things including the space and spatial relations. Diverse secondary modelling systems based on the verbal language have their special means to create peculiar models of space - in mythology, in literature, in scientific theories, in natural philosophy, etc. (cf., for example, Cassirer 1923-29, 1985; Lotman 1992b; Neklyudov 1972; Toporov 1983). All these ideal models of space and spatial formations can have their modelling function due to a structural resemblance to their objects. However, these mental models of space are not spatial models in the sense discussed above as their semantic structures do not form spatial relations. For example, it would be incorrect to say that the meanings of the words 'above' and 'below' form spatial relations, although these words are included in the modelling system of a language able to describe such relations.

\subsubsection{On the visual models of space}

There are also internal models of space which at the same time are spatial models because their elements are regulated by spatial relations. Particularly, diverse visual images of spatial objects belong to the class of spatial models in case their elements form spatial relations. For example, the parts of a visual perceptual image of a spatial situation can be connected by relations 'left-right', 'top-bottom', etc., and form a spatial structure. If this structure is similar to the perceived situation, one can consider such a perceptual image as its internal spatial model.

The perceptual model of a situation presents it as something that remains relatively constant independent of the point and angle of view, the distance from the viewer, the motions of his head, etc. For instance, the visible properties of a white rectangular sheet of paper lying in front of the observer remain the same, when this observer is turning his head and looking at the same sheet sideways. However, the observer can pay attention to some visible data, which change, depending on the turning of his head. Then, instead of a rectangular sheet the viewer can see a trapezoidal light spot changing its form and proportions. Fixation of such changes needs another way of vision. Instead of an external object which does not change, the viewing subject reflects his perception and finds the changeable sensorial data determined by relations between his eye and the object. Although the difference between these two ways of vision usually remains unnoticed, everybody can notice it when turning their head and making sure that the light and dark spots correlating with 
visible objects move to the left or to the right and change their shapes, although the objects do not change their places. Such a difference is well known to psychologists and was described, for example, by James Gibson as the difference between the 'visible world' and the 'visual field' (see Gibson 1950).

There is a third way of vision - remembering or imagining of a spatial situation with the eyes closed. All these ways of vision are the forms of human activity performed on diverse levels of the psyche. According to the Russian psychologist Boris Ananiev, the visual system has sensorial, perceptual and apperceptual levels of functioning (see Ananiev 1977: 127). Each of these ways of vision forms a basis for mental models of space, which differ by their elements, structures and functions. The internal spatial models developed on the sensorial level are open to the reflecting subject as the condition of his visual field. They relate visible spatial objects to the body of the subject framing their optical image into the system of anthropomorphic coordinates with its constant oppositions 'centre' - 'periphery', 'high' - 'low', 'right' 'left', etc. The perceptual models provide information about the relations between these objects independently of their position towards the subject's body, the lighting, etc. Finally, the apperceptual models allow operating schematized spatial images irrespectively of the position of the subject's body or the arrangement of the objects.

All these internal spatial models have definite functions in human activity. As levels of knowledge and reproductive models, they perform a cognitive function. The images of spatial forms and their arrangement can also be productive models of some created objects and planned actions.

\subsection{Semiotic means of spatial modelling}

\subsubsection{Spatial codes as modelling systems}

Spatial modelling is possible using various semiotic means. There are certain spatial codes regulating creation and interpretation of meaningful relations between spatial forms. These forms become elements of the plane of expression in spatial codes and can have both modelling and communicative functions (see Tchertov 1997, 2002, 2014). Communication via these semiotic systems addresses different modalities of feelings. For example, Braille's alphabet is a spatial code addressing the tactile senses. However, most spatial codes are oriented towards the visual-spatial channel of connection and can be called visual-spatial codes.

All these codes have spatial elements and structures on the plane of expression, but only some of them have spatial relations on the plane of the content. So the architectonic code links the relations between forms in the visible space with kinesthetic feelings (see Tchertov 1997, 2010). Due to this code the space is modelled as a "power field", in which the visible objects become indexes of invisible mechanical 
forces acting in this space and are interpreted as being in dynamic relations: 'heavier' or 'lighter', 'balanced' or 'unbalanced', 'mobile' or 'stabile', etc. (cf. Arnheim 1977).

In a different way, space is modelled by the means of the object-functional code which establishes stable connections between recognizable object forms and their instrumental functions. The forms of utilitarian objects in this code represent the forthcoming actions for which they are intended. Both the visible forms and the schemes of actions associated with them are constantly reproduced in culture and are correspondingly included in the planes of expression and content in this code (see Tchertov 1997). Space is modelled by this semiotic system as an area of action in which a subject of activity transforms some objects using tools recognized and interpreted by the means of this code.

Unlike them, the proxemic code is a semiotic system in which spatial relations between human bodies represent non-spatial social relations between the persons. According to this code the relations 'higher'-'lower', 'centre'-'periphery', etc., can build spatial structures similar to some social structures, and therefore have a modelling function.

The alphabetic script can be considered as one more visual-spatial code representing and modelling certain non-spatial referents. A succession of letters representing the phonemes of oral speech can be a visible spatial model of their audible temporal succession due to the similarity in their order. In this case the modelling functions are performed by a written succession which forms a spatial text.

\subsubsection{Spatial texts as external models}

The concept of spatial text in the broad sense can be applied not only to written texts but also to any complex of spatial objects if it is organized and comprehended by a spatial code and used to express some meanings. Spatial texts have the same specific feature as spatial codes: their plane of expression is formed by spatial relations between co-existing objects. These relations are essential not only for the 'substance', but also for the 'form' of expression because several syntactic structures of these texts can be realized only in a non-dimensional and reversible space (see Tchertov 2000, 2002, 2014).

Spatial texts are regulated by spatial codes as speech is regulated by verbal language, as Saussure described their relation. A spatial code is a system of norms common to many cases of creation and interpretation of spatial texts by diverse participants of communication.

Depending on the codes regulating spatial texts they form autonomous spaces with different properties. For example, if the autonomous space of a written text becomes structurally similar to one-dimensional temporal succession of represented phonemes, the spatial text of a geographic map forms a two-dimensional 
autonomous space, whereas the space semiotized by the proxemic code can be formed by three-dimensional texts.

Spatial texts perform the modelling function differently from codes. Unlike sign systems serving as internal models, texts can become external models of represented objects. Both these texts and external spatial models have common properties: both are formed by spatial relations and open to external feelings mostly as visible objects existing in material bearers. Each external spatial model has the features of texts if its construction and interpretation is regulated by a semiotic system and if it is possible to make a distinction between its plane of expression and plane of content.

Spatial texts can model some phenomena perceived by the senses as, for instance, a written text models oral speech. At the same time, these texts can be the models of some ideal objects: scientific concepts, mythological ideas, social notions, etc. For example, texts built according to the languages of formal logic or mathematics can be spatial models of non-spatial logical or mathematical structures insofar as there is a similarity between them.

\subsubsection{Spatial means of modelling and verbal language}

It is typical for spatial models to function as the means of visualization of some ideal objects and of non-spatial relations. For instance, logical relations can be represented by spatial models such as Leonard Eiler's circles, John Venn's diagrams, etc. At the same time, verbal language is necessary for understanding such visualized forms on a conceptual level. These spatial texts can be translated into a verbal language and appropriate semiotic systems can be considered as secondary to it.

In a similar way, diverse ideographic systems regulate connections between visible spatial forms and some notions which can be represented in verbal form as well. There is also a pictographic way of writing which is used to express verbalized meanings through more or less codified depictions. Such a pictographic way of expression together with the colour code is used in the heraldic semiotic system, which cannot be interpreted without connection with verbal language either.

However, it would be incorrect to regard all spatial codes as secondary systems since several of them have their own non-verbal grounds and can be considered as primary systems as well (cf. Lotman 1992a: 142). Particularly, the above-mentioned architectonic and object-functional codes have such basis in the experience of moving in a spatial milieu and in the praxis of operation with tools.

The problem of dependence or independence of semiotic systems on or from one another can be clarified by determining their relation to the levels of internal modelling. Verbal language provides the main semiotic means for building models on the conceptual level and on the level of imagination. However, these means are not intended for creating internal models on lower levels. For example, verbal language 
makes it possible to imagine the objects described, but does not make it possible to perceive them. However, there are visual-spatial codes which can do that.

Such semiotic systems are connected with the interpretation of external spatial models on the perceptual level of internal modelling. Internal models of space, as it was mentioned above, can be formed both on the conceptual level and on the level of perception. Accordingly, external spatial models can be related to each of these levels and there is a well-known type of spatial modelling intended for the perceptive level of interpretation - depiction.

\section{Spatial modelling by means of depictions}

\subsection{Depictions as spatial models}

Every depiction can be considered, taking into account two types of relations: one with a depicted object and the other with a perceiving subject. Both are connected with the modelling functions, but in different ways. Depiction is a reproductive spatial model of the depicted object insofar as it imitates some spatial relations between forms or colours of this object. It is also a productive model for a subject as the latter's perceptual image is formed under its influence. This second aspect is even more important than the first one.

Any representation is based on a "shifted understanding", when the attention of the interpreter turns from the recognition of the presented semiotic means to represented objects which differ from them. There are various forms of shifted understanding. Shifted comprehension is connected with changing the concept used to interpret the semiotic means; it takes place when these means evoke thoughts about something else irrespective of its ability to be perceived in the present situation. Shifted recognition is connected with changing schemes of recognizing; it takes place when a visible thing is recognized as anything different from itself - for example, if a piece of marble is recognized as a woman. Shifted perception is connected with changing perceptual images; it takes place when a visible object is perceived as something different from this object - for example, if a flat canvas covered with paint is perceived as a three-dimensional room extending behind this canvas. Shifted perception does not coincide with shifted recognition because it can be built without using any scheme of recognition, or using the same scheme in different ways (for example, in the case of the Necker cube with two possible perceptual interpretations of the same depiction - see Figure 3 below).

Each depiction on a flat surface is based on shifted perception. Its specific feature as a means of pictorial representation is its ability to evoke not only thoughts about an absent object, but also to stimulate its perception. It would be incorrect to believe that the viewer can perceive only the objects which actually exist in the situation of 
the viewing. Depiction can be defined as a visible object, which can stimulate visual perception of another visible object independently of its presence or absence in the situation of viewing. Indeed, depiction has the ability to show absent and represented objects as presented and perceived ones.

This ability to direct a subject's perception is necessary for each depiction, whereas there may be no similarity to another object. The depiction of a fantastic creature cannot be similar to it if this creature does not exist (because each relation needs at least two members), but the subject can perceive a represented fantastic creature as something existing and even present in the situation if the depiction shows it to him.

Furthermore, speaking only about depictions of existing objects, one can see that something in them has to differ in order for the picture to look more like the object of representation. To create visual perception of a depicted object, a depiction needs to be both similar and different from it. As a model, it repeats any quality of the represented thing, but as a spatial text it points out such peculiar properties of volume that cannot be reproduced directly on a flat surface. So mimesis and semiosis interact in the depiction.

\subsection{Depictions as spatial texts}

Each picture considered both as a spatial model and as a spatial text can be divided into two spaces: the depicting and the depicted ones. As mentioned above, both of them are autonomous spaces which have different as well as common properties. The flat, rectangular and closed space of the depicting surface is not identical to the depicted three-dimensional, non-bordered and open space. The former can be a model of the latter if something common to both of them is used as the basis of modelling. At the same time, the elements and structures of the depicting space can represent some objects of the depicted space even without being similar to them. These elements and structures form the plane of expression in the peculiar spatial text of the depiction, in which the plane of content is formed by represented objects.

The difference between both these planes is less obvious in a picture than it is in verbal texts, because the depicted space can be open for the viewing as well as the depicting surface which is partly similar to it. Here one visible space represents another visible space and is literally "transparent for the meaning". The representing and represented spaces constitute the planes of expression and of content of the depiction, and they are connected more closely than the two sides of the paper in Saussure's famous comparison, since they belong to the same side. 


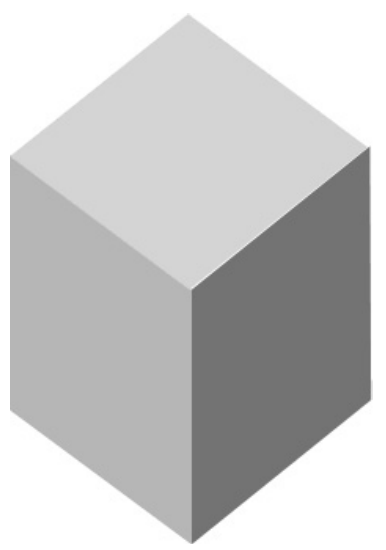

Figure 1.
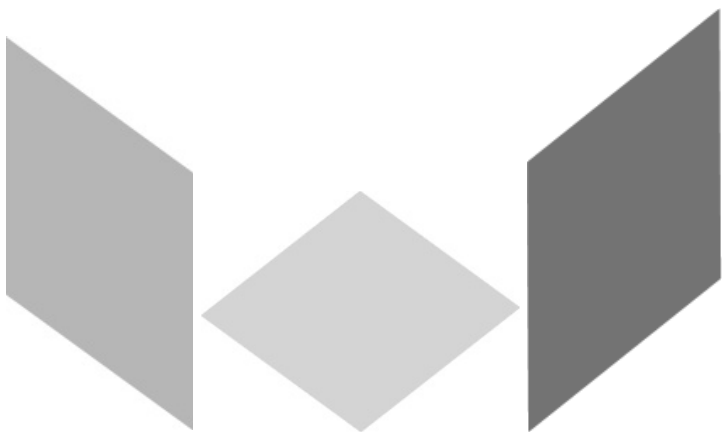

Figure 2.

Transition from the depicting space to the depicted one occurs due to shifted perception, when the looking at a surface turns into looking through it. This shift can be illustrated by the following example. Figure 1 can be viewed in two ways: as a cube and as three rhombs which are also repeated in another position in Figure 2. It is possible to see the cube due to perception that has shifted from the flat surface of paper to the depicted space where a three-dimensional cube is situated and where the rhombs are perceived as its rectangular faces.

Similarly, shifted perception occurs if the same lines of the drawing can be perceived as convergent and lying on the surface of the picture or as parallels going deep into the background of the depicted space (Figure 4). Again, there are two different modes of vision evoked by the same physical object. The first one is to look at the surface, which is necessary for creating and evaluating the depicting space in the plane of expression. The second one supposes looking through the depicting surface into the depicted space, and it is necessary for seeing the represented object.

\subsection{Perceptographic code as a system of norms correlating depicted and depicting spaces}

Relations between the depicting plane of expression and the depicted plane of content depend on the cultural norms of pictorial modelling. These norms can demand, for instance, that an artist should draw using systems of "direct", "reverse", or "parallel" perspective. They can also demand showing forms without shades, by black and white contrasts of shadow and light, by demonstrating tonal nuances between them, 
etc. According to such norms, a pictorial "window" into the depicted space can be either "clearer" for a viewer (as in 15th-19th-century painting) or more "opaque" (in painting starting with the Impressionists).

Some of these cultural norms limit the selection of features of similarity between spatial models and represented objects. The similarity can be established between diverse volumetric forms, colours, lineal structures, etc. Various types of spatial modelling are limited by these different features. So sculpture repeats forms without using colours, while painting, on the contrary, reproduces colours on a flat surface without directly imitating volumes which are represented only in the depicted space.

These cultural norms of mimetic reproduction still do not form any semiotic systems as they determine only the qualities of similarity, whereas an actual semiotic system mediates relations between the texts and the objects which do not look like them. So, the means of representation of depicted objects form a semiotic system insofar as their planes of expression and content differ from each other.

The difference between these two planes has been shown in Figure 1, where nonrectangular rhombs from the plane of expression turn into square faces of the cube represented on the plane of content. The transformation of squares into rhombs reduces the similarity between depicting and depicted forms, but increases the possibility of showing a three-dimensional form. Such deviations from the represented objects are neither iconic nor conventional signs, but the indexes pointing at the position of the represented forms in a third dimension which is absent on the depicting surface. Likewise, a complex of convergent lines and perspective shortening is a number of indexes showing parallels moving into the depth. In the same way, the system of light and shade contains indexes of volumetric forms and of their spatial arrangement.

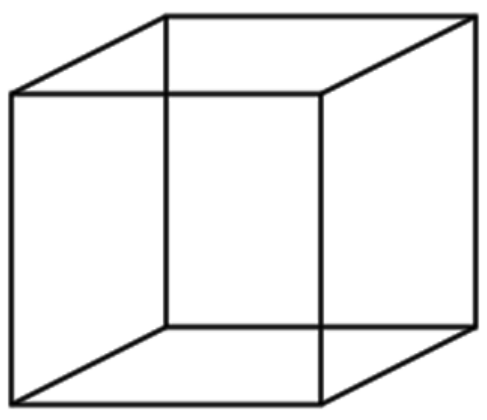

Figure 3.

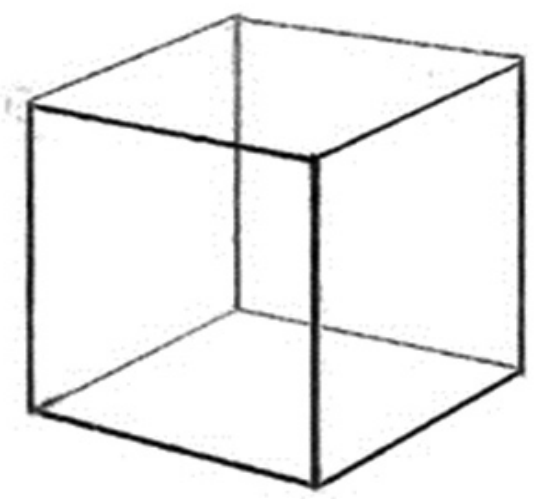

Figure 4. 
In depictions these indexes can be combined with some mimetic elements in different proportions, depending on the system of cultural norms. If one compares two flat depictions of a cube, it is obvious that the axonometric projection (Figure 3 ) has more similar features with the cube than the linear perspective (Figure 4). Figure 3 preserves the parallelism of all the parallel cube edges and the square form of two of the cube's sides. Figure 4 retains neither the parallelism of horizontal lines nor the square form of any cube faces, nor any right angles. However, this flat depiction can create a more illusory image of the cube because all these deviations from iconicity in the system of linear perspective together with a difference of contrasts on the first and the second planes in a system of aerial perspective become indexes of the stereometric form in a three-dimensional space.

Cultural norms of such a correlation between the depicting and the depicted spaces establish a particular semiotic system - a "perceptographic code" (see Tchertov 2005). This code provides means for artificial stimulation of perceptual images which are used to represent depicted objects and for communication between subjects. These means are elaborated within the historical practice of creation and interpretation of such depictions as pictures, drawings, etc. As a culturally determined system of separating and using some natural indexes, it can be called a "secondary" semiotic system only in relation to the "primary" natural perceptual code, which mediates each visual perception, but not in relation to verbal language.

The perceptographic code is connected with psychical levels, which differ from levels correlated with verbal language. The mental models of its content plane are built on the perceptual level, whereas the plane of expression is intended for the sensorial level of vision. The means of this code shift perception from the depicting to the depicted space. This code does not include upper levels of picture interpretation regulated by other visual codes and verbal language.

The system of perceptographic code does not contain separate units with constant meanings such as a vocabulary of a language. Even more than verbal language, this system can be characterized by Saussure's idea that there is nothing besides relations. Only relations between lines, tonal or colour spots, their contrasts and nuances form a complex of indexes influencing the perception of a depicted object. Together with genuine iconic features repeating the properties of an original, these indexes create an impression of "resemblance" between the depiction and its object.

\subsection{Connections between the levels of spatial modelling in depiction}

Obviously, a picture can serve not only to stimulate perception artificially, but also to express and communicate the senses developing on higher psychical levels. The painted depiction can be a mediator between the internal models built on diverse 
mental levels by the participants of communication via the picture. As a painted surface it can exteriorize a definite pattern of the painter's visual field and evoke similar conditions on the viewers' sensorial level. As a visual text regulated by the perceptographic code and forming a depicted space, it represents images of figures built on the perceptual level. These depicted figures together with spatial relations between them can also serve as visible spatial texts interpreted on apperceptual and conceptual levels by other spatial codes: object-functional, social-symbolic, proxemic ones, etc. The perceptographic code serves as a basis and a condition for application of several other visual codes by interpretation of depiction.

Thus, such a depiction is not a simple text, but a "hypertext" containing several visual-spatial texts built by various spatial codes and addressed to diverse mental levels of an interpreter. Each of these texts can perform a modelling function in relation to the represented object if there is a similarity between them. The structural similarity between these levels provides conditions also for their mutual modelling if their structures represent each other.

For example, the famous crosswise scheme of the "world tree" has an invariant structure constructed by the relations between the main axes of anthropomorphic coordinates mediating 'top' and 'bottom', 'right' and 'left', 'forward' and 'backward' as well as by the general opposition 'centre' - 'periphery' (see Toporov 1971, 1972, 1983). This invariant spatial structure is included in many external models (both figurative and non-figurative), and it can also pass through all internal levels of spatial modelling. This structure organizes the visual field on the sensorial level and it is projected onto the "regular field" of the rectangular plane of the picture (see Shapiro 1994; Daniel et al. 1979). It also forms the general structure of the perceptible space on the level of the "visible world" as well as the spatial structure of many visible forms - anthropomorphic, zoomorphic, phytomorphic, etc. It is also reproduced on the apperceptual level as a scheme of some recognizable objects: a human body, a temple, a vessel, etc. This invariant spatial scheme is also actualized by interpreting spatial relations between the bodies of people by means of the proxemic code or between the members of some sacred hierarchy by means of the "hierophanic" code.

In all these cases, the represented content becomes visible due to this crosswise spatial scheme being directly presented for a viewer. At the same time, this scheme structuring each level of such a multilevel spatial hypertext is essential not only as a peculiarity of its expression plane, but also as an alienable part of its content. Such a spatial text is not equivalent to any verbal text built as linear succession; nor can it be considered as its simple translation. For example, medieval depictions of the subjects of the Holy Scripture are not its visual translation, but spatial models of the structure of the world, which is not directly described, but only presumed in the verbal text. The spatial scheme of the "world tree" represents invariants not of any verbal 
texts, but of internal semantic structures of language and of several other modelling semiotic systems deriving from it. The content, which the language has in its internal system among its paradigmatic structures, spatial models present by the syntagmatic structures of visible spatial texts

So the spatial way of modelling allows visualizing some conceptual structures which cannot be perceived in any other way. This unique ability of synoptic comprehension of complex structures makes spatial modelling an irreplaceable method of representation.

\section{References}

Ananiev, Boris 1977. O problemah sovremennogo chelovekoznaniya. Moscow: Nauka. Ананьев, Б. Г. 1977. О проблемах современного человекознания. Москва: Наука.

Arnheim, Rudolf 1977. The Dynamics of Architectural Form. Berkeley, Los Angeles: University of California Press.

Bühler, Karl 1934. Sprachtheorie. Die Darstellungsfunktion der Sprache. Jena: Verlag von Gustav Fischer.

Carnap, Rudolf 1922. Der Raum. Ein Beitrag zur Wissenschaftlehre. Berlin: Reuter und Richard.

Cassirer, Ernst 1923-29. Philosophie der symbolischen Formen. Bd. I-III. Berlin: Bruno Cassirer.

- 1985. Mithischer, ästhetischer und theoretischen Raum. In: Cassirer, Ernst. Symbol, Technik, Sprache: Aufsatze aus d. Jahren 1927-1933. Hamburg: Mainer Verlag, 93-119.

$\mathrm{CP}=$ Peirce, Charles S. 1931-1935.

Daniel, Aleksandr M.; Daniel, Sergej M. 1979. Regularnoe pole izobrazheniya kak ob’ekt semioticheskogo analiza. In: Teoreticheskie problemy dizajna. Metodologicheskie aspekty sotsiologicheskih $i$ istoriko-kul'turnyh isseldovanij. Moscow: VNIITE, 75-80. Даниэль, Александр М.; Даниэль, Сергей М. 1979. Регулярное поле изображения как объект семиотического анализа. In: Теоретические проблемы дизайна. Методологические аспекты социологических и историко-культурных исследований. Москва: ВНИИТЭ: $75-80$.

Gibson, James J. 1950. The Perception of the Visual World, Boston: Houghton Miffin Company.

Hjelmslev, Louis 1953. Prolegomena to a Theory of Language. Baltimore: Indiana University Publications in Anthropology and Linguistics (Memoir 7): Waverly Press.

Ivanov, Vyacheslav V.; Lotman, Juri M.; Pjatigorski, Alexander. M.; Toporov, Vladimir N.; Uspenskij, Boris A. 1998. Theses on the Semiotic Study of Cultures. Tartu Semiotics Library 1. Tartu: Tartu University Press.

Jakobson, Roman 1972. K voprosu o zritel'nyh i sluhovyh znakah. In: Semiotika $i$ iskusstvometriya. Moscow: Mir, 82-87. Якобсон, Роман 1972. К вопросу о зрительных и слуховых знаках. In: Семиотика и искусствометрия. Москва: Мир, 82-87.

Lotman, Juri M. 1967. Tezisy k probleme "Iskusstvo v ryadu modeliruyushchih sistem". Sign Systems Studies 3: 130-145. Лотман, Ю. М. 1967. Тезисы к проблеме «Искусство в ряду моделирующих систем». Труды по знаковым системам 3: 130-145. 
- 1984. O semiosfere. Sign Systems Studies 17: 5-23. Лотман, Ю. М. 1984. О семиосфере. Труды по знаковым системам. (Структура диалога как приниип работы семиотического механизма.) 17: 5-23.

- 1992a. Tekst i poliglotizm kul'tury. In: Lotman, Juri. Izbrannye stat'i. Vol. 1. Stat'i po semiotike i tipologii kul'tury. Tallinn: Aleksandra, 142-147. Лотман, Ю. М. 1992а. Текст и полиглотизм культуры. In: Лотман, Ю. М. Избранные статьи. Т. 1. Статьи по семиотике и типологии культурь. Таллинн: Александра, 142-147.

- 1992b. Problema hudozhestvennogo prostranstva v proze Gogolya. In: Lotman, Juri. Izbrannye stat'i. Vol 1. Stat'i po semiotike i tipologii kul'tury. Tallinn: Aleksandra, 413-447. Лотман, Ю. М. 1992b. Проблема художественного пространства в прозе Гоголя. In: Лотман, Ю. М. Избранные статьи. Т. 1. Статьи по семиотике и типологии культуры. Таллинн: Александра, 413-447.

- 1998. Ob iskusstve. St-Petersburg: Iskusstvo-SPb. Лотман, Ю. М. 1998. Об искусстве. С.Петербург: Искусство-СПб.

Meyer-Eppler, Werner 1959. Grundlagen und Anwenungen der Informationstheorie. Berlin, Heidelberg: Springer Verlag..

Morris, Charles 1971a. Foundations of the theory of signs. In: Morris, Charles. Writings on the General Theory of Signs. The Hague, Paris: Mouton, 7-71.

- 1971b. Signs, language and behavior. In: Morris, Charles. Writings on the General Theory of Signs. The Hague, Paris: Mouton, 75-399.

Neklyudov, Sergej 1972. Vremya i prostranstvo v byline. In: Slavyanskij fol'klor. Moscow: Nauka, 18-45. Неклюдов, С. Ю. 1972. Время и пространство в былине In: Славянский фольклор. Москва: Наука, 18-45.

Peirce, Charles Sanders 1960. Collected Papers of Charles Sanders Peirce. Cambridge: Harvard University Press. [Hartshorne, Charles; Weiss, Paul (eds.); in-text referendes are to CP, followed by volume and paragraph number.]

Russell, Bertrand 1997. Chelovecheskoe poznanie. Ego sfera i granitsy. Kiev: Nica-Centr. Рассел, Б. 1997. Человеческое познание. Его сфера и гранищы. Киев: Ника-Центр.

Saussure, Ferdinand de 1977. Kurs obschej lingvistiki. In: Trudy po yazykoznaniyu. Moscow: Progress. Соссюр, Ф. де. Курс общей лингвистики. In: Труды по языкознанию. Москва: Прогресс 1977. (Orig: Saussure, Ferdinand de. Cours de linguistique générale. 1916).

Schreider, Julij A. 1974. Logika znakovyh sistem. Moscow: Znanie. Шрейдер Ю. А. 1974. Логика знаковых систем. Москва: Знание.

Tchertov, Leonid 1993. Znakovost'. Opyt teoreticheskogo sinteza idej o znakovom sposobe informatsionnoj svyazi. St.-Petersburg: St.Petersburg State University Press. Чертов, Л. Ф. Знаковость. Опыт теоретического синтеза идей о знаковом способе информационной связи. Санкт-Петербург: Издательство С.-Петербургского гос. университета.

- 1997. The semiotization of space and dynamic codes. Semiotica 114(3/4): 287-293.

- 1999 = Čhertov, Leonid. The sign prizm: A spatial model of semiosis. European Journal for Semiotic Studies 11(1-3): 57-73.

- 2000. On structural peculiarities of spatial texts. In: Pellegrino, Pierre (ed.), L'espace dans l'image et dans le texte: Colloque d' Urbino. Urbino: Edizioni Quattro Venti, 41-50.

- 2002. Spatial semiosis in culture. Sign Systems Studies 30(2): 441-454. 
- 2005. Perceptographic code in visual culture. Sign Systems Studies 33(1): 137-158.

- 2010. On visual-spatial codes in architecture. Environment, Land, Society: Architectonics. [Space, Time, Semiotics] 2(1-2): 73-89.

- 2014. Znakovaja prizma. Stat'i po oshchej i prostranstvennoj semiotike. Moscow: Yazyki slavyanskoj kul'tury. Знаковая призма. Статьи по общей и пространственной семиотике. Москва: Языки славянской культуры.

Toporov, Vladimir N. 1971. O strukture nekotoryh arhaicheskih tekstov, sootnosimyh s kontseptsiej „mirovogo dereva“. Sign Systems Studies 5: 9-62. Топоров, B. H. 1971. O структуре некоторых архаических текстов, соотносимых с концепцией “мирового дерева”. Труды по знаковым системам. 5: 9-62.

- 1972. K proishozhdeniyu nekotoryh poetichekih simvolov. Paleoliticheskaya epoha. Rannie formy iskusstva. Moscow: Iskusstvo, 93-98. Топоров, В. Н. 1972. К происхождению некоторых поэтических символов. Палеолитическая эпоха. Ранние формы искусства. Москва: Искусство, 93-98.

- 1983. Prostranstvo i tekst. Tekst: semantika i struktura. Moscow: Nauka, 227-285. Топоров В. Н. 1983. Пространство и текст. Текст: семантика и структура. Москва: Наука, 227-285.

Shapiro, Meyer 1994. On some problems in the semiotics of visual art: Field and vehicle in image-signs. In: Shapiro, Meyer. Theory and Philosophy of Art: Style, Artist, and Society. Selected Papers. Vol. 4. New York: George Braziller, 1-32.

Vygotskij, Lev 1983. Istoriya razvitiya vysshih psihicheskih funktsij. In: Problemy razvitiya psihiki. Sobranie sochinenij, vol 3. Moscow: Pedagogika. Выготский, Л. С. 1983. История развития высших психических функций. Собрание сочинений. Т. 3. Проблемы развития психики. Москва: Педагогика.

Wittgenstein, Ludwig 1922. Tractatus Logico-Philosophicus. (Ogden, Charles Kay, trans.; Russell, Bertrand, intr.) London: Routledge \& Kegan Paul.

\section{О пространственном моделировании}

Пространственное моделирование имеет место в тех случаях, когда пространственные структуры участвуют в образовании моделей, и когда они сами становится моделируемым объектом. Пространственные модели рассматриваются в статье как средства человеческой деятельности в обоих ее аспектах: внешнем и внутреннем. Внешние пространственные модели представляют собой чувственно воспринимаемые объекты, имеющие структурное сходство с чем-то иным и способные репрезентировать его для субъекта-интерпретатора. Их интерпретация может производиться на разных ментальных уровнях: сенсорном, перцептивном, апперцептивном и концептуальном, каждый из которых также может рассматриваться как особый способ построения внутренних моделей. И внешние, и внутренние пространственные модели могут быть как продуктивными, так и репродуктивными, в зависимости от того, служат ли они образцом для воспроизведения или же, наоборот, сами строятся как воспроизведения некоторого образца. Внешние модели могут рассматриваться как пространственные тексты, если в них могут быть вычленены план выражения и план содержания, связанные между собой с помощью определенной семиотической системы. В частности, 
эти два плана обнаруживаются у изображений, где можно видеть как изображающее, так и изображаемое пространства, связанные между собой с помощью индексов особого перцептографического кода. Таким образом, изображения могут пониматься как пространственные тексты, интерпретируемые, во-первых, на перцептивном уровне внутреннего моделирования, а, во-вторых, на более высоких уровнях сознания с помощью других визуально-пространственных кодов.

\section{Ruumilisest modelleerimisest}

Ruumiline modelleerimine puudutab nii juhtumeid, mil ruumilistel struktuuridel on modelleeriv funktsioon, kui ka juhtumeid, kui sellistest struktuuridest saavad modelleeritavad objektid. Artiklis vaadeldakse ruumilisi mudeleid kui inimtegevuse vahendeid lähtuvalt nii välistest kui ka sisemistest aspektidest. Välised ruumilised mudelid on meeltega tajutavad objektid, mis struktuurilt sarnanevad millegagi, mis neist erineb, ja saavad seda kujutada kui oma subjekti. Neid on võimalik tõlgendada mitmesugustel mentaalsetel tasanditel: sensoorselt, pertseptuaalselt, apertseptuaalselt ja kontseptuaalselt, mis kõik on seotud sisemise modelleerimise ühe omapärase laadiga. Nii välistel kui ka sisemistel ruumilistel mudelitel võib olla produktiivne või reproduktiivne iseloom, mis sõltub sellest, kas nad esinevad reproduktsioonimallidena või on originaalide koopiad. Väliseid mudeleid on võimalik pidada ruumilisteks tekstideks, kui neid saab jagada väljendusplaaniks ja sisuplaaniks, mida seob omavahel mingi semiootiline süsteem. Eriti võib selline jaotus tulla ilmsiks kujutamise puhul, milles nii kujutava kui ka kujutatava ruumi tasandid on vaatamiseks avatud ja nende seost reguleerivad spetsiaalse pertseptograafilise koodi indeksid. Seega võib kujutamist kohelda ruumilise tekstina, mida tõlgendatakse esmalt sisemise modelleerimise pertseptuaalsel tasandil ja teiseks kõrgematel mentaalsetel tasanditel muude ruumilis-visuaalsete koodide abil.

Artikkel on jagatud kolmeks. Esimeses osas kirjeldatakse põhimõisteid, nagu autor neid käsitleb. Teises osas rakendatakse neid mõisteid ruumilise modelleerimise kontseptsioonile ja selle semiootilistele vahenditele. Kolmandas osas käsitletakse ruumilise modelleerimise tähtsat erijuhtumit: mimeetiliste ja semiootiliste vahendite kombineerimist kujutamisel. 